\title{
Impact of Lawn-care Firm Characteristics on Pesticide Expenditures
}

\author{
W.J. Florkowski ${ }^{1}$ and E.E. Hubbard ${ }^{2}$ \\ Department of Agricultural and Applied Economics, University of Georgia, \\ Georgia Experiment Station, Griffin, GA 30223-1797
}

G.W. Landry ${ }^{3}$ and T.R. Murphy ${ }^{3}$

Department of Crop and Soil Sciences, University of Georgia, Georgia Experiment Station, Griffin, GA 30223-1797

Additional index words. herbicides, insecticides, fungicides, residential landscape, commercial landscape, gross revenue

\begin{abstract}
Using three types of pesticides is related to selected lawn-care firm characteristics. The data were collected through a survey of 95 randomly selected firms, which yielded 68 usable questionnaires. From that number, 50 firms specializing in lawn-care services other than mowing were selected. Statistical relationships were formulated using herbicide, insecticide, and fungicide expenditures as dependent variables. In estimated relationships, the impact of variables significantly different from zero (i.e., firm's gross revenue, number of commercial customers serviced, annual labor cost, and size of the treated commercial landscape) was in the same direction but differed in magnitude. In general, commercial account additions and firm size (measured by gross revenue) increased pesticide expenditures. Pesticide expenditures decreased, however, as the labor cost and the size of the treated commercial landscape increased. The firm's perception of pesticide regulations had no impact in the specified relationships.
\end{abstract}

The residential and commercial lawn-care industry is a viable and growing service business (Professional Lawn Care Association of America, 1989). With the commercial landscapes development and the increased emphasis on residential landscapes, landscape firms offer specialized and nonspecialized lawncare services. Population growth in the southern United States coupled with increased emphasis on residential and commercial landscapes, offer an opportunity for establishing and expanding businesses specializing in lawn care.

In Georgia, weeds are a major turfgrass pest, followed by disease and insect problems. Spring and summer weed problems include crabgrass (Digitaria sanguinalis L.) and goosegrass [Eleusine indica (L.) Gaertn.]; in fall, winter, and late spring, problems include annual bluegrass (Poa annua L.), henbit (Lamium amplexicaule L.), clovers (Trifolium spp.), and dandelions (Taraxacum officinale Weber). The increase of environmental con-

Received for publication 27 May 1993. Accepted for publication 19 May 1994. We thank J.C. Purcell and R.N. Carrow for their comments on earlier drafts of this paper. We also appreciate the assistance of M. Lusk, M. Slocum, and H. Witt in preparing this paper. The cost of publishing this paper was defrayed in part by the payment of page charges. Under postal regulations, this paper therefore must be hereby marked advertisement solely to indicate this fact.

${ }^{1}$ Associate Professor.

${ }^{2}$ Research Coordinator I.

${ }^{3}$ Extension Agronomist. cerns influences new landscapes and lawn management practices. Pesticide use is subject to increased regulation and may change in response to customer demands. For example, some herbicides may negatively affect landscaped yards (Geyer and Long, 1991) or cause turf injury (McCarty and Colvin, 1992; Shim and Johnson, 1992).

Our objective was to provide insight on herbicide, insecticide, and fungicide usage by the lawn-care industry in Georgia. The three types of pesticides relate to various firm characteristics. Our results should identify factors that influence pesticide use by lawn-care firms, thereby providing guidance to researchers, extension personnel, and the industry concerning possible adjustments in pesticide use. Our literature search did not yield a publication describing lawn-care firm pesticide expenditures. Thus, this information should be useful in illustrating pesticide use that already has caused controversy in some areas (Funk, 1992).

\section{Materials and Methods}

Our data were collected through a survey of the 18-county, metropolitan-Atlanta, statis- tical area. A list of 271 professional lawn-care firms was compiled with the help of county extension offices, business listings in the telephone book, and personal knowledge of the industry. A 95-firm sample was randomly selected from the total population.

A one-page, confidential questionnaire with a cover letter from the Univ. of Georgia's extension turfgrass specialist and the president of the Georgia Turfgrass Foundation was mailed to each firm in the sample. After 3 weeks, nonrespondents were mailed a second letter. An enumerator contacted (either by phone or personal visit) those who still did not respond. Alternates were selected for nonparticipants. After such considerable efforts to contact lawn-care firms, usable questionnaires were obtained from 68 firms. Pesticide use is based on the responses provided by 50 of those 68 firms (53\% of the selected sample). The remaining 18 firms specialized in mowing services and were excluded. Data were collected during 1988 for the 1987 calendar year. The relationships were tested statistically using the ordinary least squares (OLS) procedure.

\section{Results}

Pesticide expenditures. Herbicides were the most frequently purchased pesticide, applied by $88 \%$ of surveyed firms (Table 1). Insecticides were purchased by $70 \%$ of firms and fungicides by $54 \%$. Most firms reporting purchases spent $\$ 1000$ or less on insecticides and fungicides, but most (52\%) spent more than $\$ 1000$ on herbicides. Preemergence herbicides are applied routinely for crabgrass control, often in combination with fertilizers, to reduce labor cost by fertilizing and controlling weeds in one visit. Insecticides, fungicides, and postemergence herbicides require more diagnosis than preemergence herbicides. In the Atlanta metro area, fungicides and insecticides may be used less frequently because the pests they control are a less serious problem than weeds.

Statistical relationships. To evaluate factors influencing pesticide use, three statistical relationships were formulated based on the survey data. In each relationship, the dependent variable was herbicide, insecticide, and fungicide use measured as annual expenditures. The independent variables included various lawn-care firm characteristics, with average values and units of measurement (Table 2 ). An average firm grossed $\$ 386,000$ annually and spent approximately $\$ 204,000$ on labor. Labor costs, measured as the annual expenditures on labor, indicated the importance of labor for the total operation of the lawn-care firm. Given the limited capital in-

Table 1. Percentage of lawn-care firms reporting expenditures for three pesticide types.

\begin{tabular}{lccccc}
\hline \hline & \multicolumn{5}{c}{ Amount of expenditures $(\%)$} \\
Type of & $\$ 1,000$ & $\$ 1,000-$ & $\$ 5,000-$ & $\$ 10,000$ & No purchase \\
pesticide & or less & $\$ 5,000$ & $\$ 10,000$ & or more & reported \\
\hline Herbicide & 36 & 36 & 12 & 4 & 12 \\
Insecticide & 50 & 18 & 2 & 0 & 30 \\
Fungicide & 46 & 8 & 0 & 0 & 46 \\
\hline
\end{tabular}


Table 2. Average values of selected lawn-care firm characteristics.

\begin{tabular}{lr}
\hline Firm characteristic & Avg value \\
\hline Total revenue $(\$)$ & 385,614 \\
No. residential accounts & 20 \\
Area residential account $\left(\mathrm{m}^{2}\right)$ & 1,004 \\
No. commercial accounts & 36 \\
Area commercial account $\left(\mathrm{m}^{2}\right)$ & 9,393 \\
Annual labor cost $(\$)$ & 204,488 \\
Herbicide purchase value $(\$)$ & 3,501 \\
Insecticide purchase value $(\$)$ & 864 \\
Fungicide purchase value $(\$)$ & 452 \\
\hline
\end{tabular}

vestment needed to establish a lawn-care firm, labor is the most important item for the firm's existence and, consequently, affects pesticide use.

The average number of commercial accounts was nearly twice the number of residential accounts (Table 2). The number of residential and commercial accounts indicated differences in the types of services demanded by residential and commercial customers. The differences are related to the ability and willingness to pay for a service and presumably reflect general attitudes of property owners toward lawn-care needs.

The size of an average residential account was about one-tenth that of an average commercial account. The size of the average residential and commercial account indicated potential pesticide use-the larger the area, the more pesticides are used to control weeds, disease, or insect problems; this is because the lawn is a larger part of the landscape and thus a larger part of the landscape investment. The firm's perception of the need for a particular treatment may depend on a specific problem, pesticide type, and application cost. The average value of herbicide, insecticide, and fungicide purchase reflects the importance of each pest problem and the relative chemical cost. On average, the surveyed firms spent several times more on herbicides than insecticides or fungicides.

In addition, two binary variables were added that reflected the firms' knowledge and expertise and the perception of pesticide regulation importance. Knowledge and expertise were represented by the firm's attendance at lawncare workshops and conferences. A firm's perception of pesticide regulation importance was reflected in a survey question that asked participants to rank pesticide regulation with five other industry problems. The question was open-ended, so respondents also could name a problem. The importance of pesticide regulations was listed among the top five problems, although rarely as the most important problem faced by a respondent. Attending workshops and conferences and ranking pesticide regulation as important were coded as one if the responding firm confirmed that its employees attended a given program and a zero if no attendance was reported.

The three specified relationships (herbicide, insecticide, and fungicide use as measured by the expenditure on those products) were estimated using the OLS procedure. Two goodness-of-fit measures were obtained. The adjusted $R^{2}$ for the three relationships ranged from 0.5604 for herbicide use to 0.6228 for insecticide use and 0.4232 for fungicide use. The $F$ values indicated that the impact of each variable set on the dependent variable differed from zero could be accepted at $\alpha \leq 0.01$.

Herbicide expenditures were positively influenced by the gross revenue reported by a lawn-care firm (Table 3). Thus, as firm revenues increased, expenditures on herbicides increased. The number of residential accounts correlated negatively with expenditures on herbicides, but the impact was not significant, as indicated by the $t$ ratio value.

In contrast, adding one commercial account to a firm's roster increased herbicide expenditures by $\$ 97$. This result was statistically significant and suggests that commercial sites are more likely to receive herbicide applications. The eye-appeal of commercial sites is important to most clients because well-maintained surroundings are the desired image.

Annual labor costs were negatively correlated to herbicide expenditures; the impact, although small, was statistically significant at $\alpha=0.01$. Commercial account size had a negative relationship with herbicide expenditures, but the result was only significant at $\alpha=$ 15. Although weak, this negative relationship between the commercial lawn size and herbicide expenditures seems justified. As the lawn size increases, the herbicide applications may be more costly to customers, leading to fewer herbicide applications.

Workshop attendance and pesticide regulation importance had positive and statistically weak relationships to herbicide expenditures. Workshop and conference attendance was expected to help describe herbicide use and demonstrate application, but apparently the variable reflecting such attendance had little impact on herbicide purchases. Similarly, the perceived importance of pesticide

Table 3. Influence of lawn-care firms' characteristics on their herbicide expenditures.

\begin{tabular}{lrrc}
\hline \hline Variable name & $\begin{array}{c}\text { Parameter } \\
\text { estimate }\end{array}$ & $t$ ratio & $\begin{array}{c}\text { Probability } \\
\text { level }\end{array}$ \\
\hline Intercept & -1358.8086 & -0.74 & 0.4630 \\
Gross revenue & 0.0178 & 4.66 & 0.0001 \\
No. residential accounts & -24.9448 & -0.61 & 0.5485 \\
No. commercial accounts & 97.1797 & 3.01 & 0.0047 \\
Annual labor cost & -0.0224 & -3.77 & 0.0006 \\
Size of treated commercial landscape & -12.6148 & -1.50 & 0.1432 \\
Workshop or conference attendance & 1253.7226 & 0.77 & 0.4457 \\
Perceived importance of pesticide & & & \\
$\quad$ regulations & 1340.7793 & 1.32 & 0.1950 \\
Adjusted $R^{2}$ & 0.5604 & & \\
F value & 8.832 & & \\
\hline
\end{tabular}

Table 4. Influence of lawn-care firms' characteristics on their insecticide expenditures.

\begin{tabular}{lrrc}
\hline \hline Variable name & $\begin{array}{c}\text { Parameter } \\
\text { estimate }\end{array}$ & $t$ ratio & $\begin{array}{c}\text { Probability } \\
\text { level }\end{array}$ \\
\hline Intercept & 218.2791 & 0.59 & 0.5574 \\
Gross revenue & 0.0044 & 5.71 & 0.0001 \\
No. residential accounts & -12.9976 & -1.57 & 0.1255 \\
No. commercial accounts & 18.7439 & 2.89 & 0.0065 \\
Annual labor costs & -0.0057 & -4.79 & 0.0001 \\
Size of treated commercial landscape & -4.8763 & -2.88 & 0.0067 \\
Workshop or conference attendance & 155.5970 & 0.48 & 0.6372 \\
Perceived importance of pesticide & & & \\
$\quad$ regulations & 151.9663 & 0.74 & 0.4619 \\
Adjusted $R^{2}$ & 0.6228 & & \\
F value & 11.144 & & \\
\hline
\end{tabular}

regulations as an industry problem had no statistically significant relationship to herbicide expenditures.

The impact direction of each variable in relation to insecticide expenditure was similar to the impact of the same variables on herbicide expenditures, but the magnitude of the impact and statistical significance differed (Table 4). Gross revenue had a statistically significant, positive impact; however, insecticide expenditures increased only marginally for every dollar increase in gross revenue. The number of residential accounts had a negative, although not statistically significant, impact on insecticide expenditures, whereas the number of commercial accounts had a positive impact on insecticide expenditures. On average, commercial accounts increased insecticide expenditures by $\$ 19$ per account. The size of a commercial landscape treated with insecicides negatively correlated to the insecticide expenditures. The decrease amounted to $\$ 5.25$ for every additional $100 \mathrm{~m}^{2}$ of treated land. The labor costs also were negatively related to insecticide expenditures. Attendance at conferences and workshops and the perception of pesticide regulation had no significant pact on insecticide use.

Fungicide expenditures were positively influenced by gross revenues (Table 5). The number of commercial accounts positively influenced expenditures; for every new commercial account added to the firm's list, the firm could expect to increase fungicide expenditures by almost $\$ 13$. Labor costs were negatively correlated to fungicide expenditures, though the impact was small.

As in the case of herbicide and insecticide expenditures, attending a workshop or a conference and perceiving pesticide regulations to be important were not significantly related to fungicide expenditures. 
Table 5. Influence of firm characteristics on fungicide expenditures by lawn-care firms.

\begin{tabular}{|c|c|c|c|}
\hline Variable name & $\begin{array}{c}\text { Parameter } \\
\text { estimate }\end{array}$ & $t$ ratio & $\begin{array}{c}\text { Probability } \\
\text { level }\end{array}$ \\
\hline Intercept & 119.9846 & 0.46 & 0.6490 \\
\hline Gross revenue & 0.0016 & 2.92 & 0.0060 \\
\hline No. residential accounts & -8.8764 & -1.51 & 0.1396 \\
\hline No. commercial accounts & 12.9564 & 2.82 & 0.0079 \\
\hline Annual labor cost & -0.0025 & -2.98 & 0.0051 \\
\hline Size of treated commercial landscape & -2.9534 & -2.46 & 0.0190 \\
\hline Workshop or conference attendance & 274.9347 & 1.19 & 0.2438 \\
\hline \multicolumn{4}{|l|}{ Perceived importance of pesticide } \\
\hline regulations & 95.6812 & 0.66 & 0.5133 \\
\hline Adjusted $R^{2}$ & 0.4232 & & \\
\hline $\mathrm{F}$ value & 5.506 & & \\
\hline
\end{tabular}

\section{Discussion}

In all three estimated relationships, the impact of variables that differed significantly from zero was in the same direction. In general, adding residential accounts did not increase expenditures on pesticides, but adding commercial accounts did.

The size of treated landscapes was negatively related to fungicide expenditures. This result was statistically significant and suggests that even commercial landscape owners were cost-conscious when applying fungicides. The labor costs also negatively affected fungi- through the survey do not include all potentially important information applicable in explaining pesticide expenditures by lawn-care firms. The impact direction of selected independent variables is considered accurate, but the specific magnitude of impacts may vary over time and across regions.

\section{Literature Cited}

Funk, R.C. 1992. The pesticide controversy-Crisis or opportunity. J. Arbor. 18(3):109-111.

Geyer, W.A. and C.E. Long. 1991. Tolerance of selected tree seed to combinations of preemergent herbicides. J. Environ. Hort. 9(1):44-46.

Hubbard, E.E., J.C. Purcell, G.W. Landry, and T.R. Murphy. 1990. An economic profile of the lawncare industry in the metropolitan Atlanta area. Georiga Agr. Expt. Sta., College of Agr., Univ. of Georgia, Spec. Publ. 65.

McCarty, L.B. and D.L. Colvin. 1992. Buffalograss tolerance to postemergence herbicides. HortScience 27:898-899.

Professional Lawn Care Association of America. 1989. Professional Lawn Care Association of America: Yesterday, today and tomorrow. Lawn Servicing Magazine, Overland Park, Kan.

Shim, S.R. and B.J. Johnson. 1992. Response of creeping bentgrass to spring-applied herbicides. HortScience 27:237-239. 